\title{
THE IMPLEMENTION OF LOCAL WISDOM IN MANAGING THE BUDGETS OF RURAL FINANCING AT PORINGAN VILLAGE IN WEST SULI DISTRICT OF LUWU REGENCY
}

\author{
Helmi Kamal \\ Jerianto \\ Dosen Institut Agama Islam Negeri Palopo
}

\begin{abstract}
The focus of this article is to explore the practical concepts of local wisdom values in managing the budgets of Rural financing at Poringan Village in West Suli District of Luwu Regency. This study also highlights the inhibiting factors for the implementation of local wisdom values in managing the budget of rural financing. For such purposes, this research applies qualitative research that enables the analysis of field evidence-based data without the involvement of statistical and numeric analysis. This study found that there were three fundamental values of local wisdom practiced in the management of budgets of rural financing. The values were concepts related to adele (just), lempu (honest) and getteng (persistent).
\end{abstract}

\begin{abstract}
Abstrak: Fokus artikel ini adalab untuk mengeksplorasi konsep-konsep praktis nilai-nilai kearifan lokal dalam mengelola anggaran pembiayaan pedesaan di Desa Poringan di Kabupaten Suli Barat, Kabupaten Luwn. Studi ini juga menyoroti faktor-faktor penghambat bagi penerapan nilai-nilai kearifan lokal dalam mengelola anggaran pembiayaan pedesaan. Untuk tujuan tersebut, penelitian ini menggunakan penelitian kualitatif yang memungkinkan analisis data berbasis buk.ti lapangan tanpa keterlibatan analisis statistik dan numerik. Studi ini menemukan bahwa ada tiga nilai mendasar dari kearifan lokal yang dipraktekekan dalam pengelolaan anggaran pembiayaan pedesaan. Nilai-nilai itu adalab konsep yang berkaitan dengan adele (adil), lempu (jujur) dan getteng (persisten).
\end{abstract}

Keywords: V alues of Local Wisdom; Budget Management; Rural Financing

\section{Background}

When the Village Law was enacted, various parties have given much appreciation to the central government for the development of previous village autonomy. At the same time with Law Number 6 Year 2014, villages in Indonesia have a better future arrangement than the previous Law, namely Law Number 5 Year 1999 concerning Villages, Law Number 22 Year 1999 concerning Regional Government and Law Number 32 Year 2004 concerning Regional Government including regulating villages in Indonesia. ${ }^{1}$.

The Rural fund allocation (hereinafter abbreviated as ADD) is currently given entirely to the village concerned to plan, implement and report the ADD provided by the central government. This is intended to accelerate the realization of community welfare through the improvement, service, empowerment and participation of rural communities, as well as increasing regional competitiveness by taking into account the principles of democracy, equity, justice, privilege and specificity of an area within the unity of the Republic of Indonesia..

\footnotetext{
1 Diantha I Made Pasek, Hukum Pidana Internasional; dalam Dinamika Pengadilan InternasionalI (Jakarta: Kencana Prenada Media, 2-14), 1.
}

Village authority to organize and manage the community independently requires the existence of reliable and capable human beings as village managers as a self governing community (a community that manages its government independently). Village regeneration is a very strategic activity for the creation of villages that are strong, advanced, independent and democratic. Village regeneration involves increasing the capacity of rural communities in all life, especially in developing capacity in democratic village management. ${ }^{2}$

The existence of these policies provides opportunities for each region to develop the potential that exists in their respective regions so that the values of local wisdom can also be one of the references in managing the village government system including those in Poringan Village, Suli Barat District, Luwu Regency who apply local values in ADD management practices.

In this context, this study focuses on identification the application of local values in the practice of managing village budget funds in Poringan Village, Suli Barat District, Luwu Regency.

\footnotetext{
2 Dindin Ghozal. Abdullah, Kader Desa: Penggerak Prakarsa Masyarakat Desa (Jakarta: Kementrian Desa, Pembangunan Daerah Tertinggal, dan Transmigrasi Republik Indonesia, 2015), 8-9.
} 


\section{Theory Study}

1. Local values of government in Luwu Regency

One of the factors that drives a society's prosperity everywhere is nothing but the enforcement of the rule of law. Anwar Ibrahim emphasises that the development of the welfare state in Luwu could not be separated from several concepts that had to be imbued, and this was the idea of Maccae Ri Luwu. Furthermore, it is said that in the implementation and enforcement of law it is very important to maintain an attitude of addiction, characterism and getteng, especially in law enforcement by holding sitina, silasana, and silempuq principles that contain obedience and reasonableness which are important guidelines in legal culture thinking in maccae thinking ri luwu. The trust of the community is exposed to the truth of the words of honesty, firmness, and wisdom of law enforcers who put everything proportionally in accordance with the principle of fairness or obedience into the joint compliance of the law itself. ${ }^{3}$

Associated with the growth and progress of the flexible unit which has been running for 12 centuries, at least caused by several factors, namely 1) The existence of To Manurung as daulah substance and at the same time proma of authority, which in turn incarnated a 'political myth', and the formation of 'Elite power' "For the offspring in the future; 2) The existence of Pangadereng as the administration of government which includes Ade '(adat), Rapoang (law), Wari (rules of social statification), Bicara (judicial), Sara (rule of Islam); 3) The existence of siri and pacce that are identical with self-esteem and solidarity which is a weltanschaunng, which is a manifestation of human existence that functions as a bond and glue of the nation.

State glory is possible by fulfilling the eight main requirements for State officials: 1) maintaining honesty; 2) always say right; 3) firm in the right position; 4) introspection; 5) be generous; 6) maintain a friendly attitude; 7) maintaining courage, and 8) not favoritism. ${ }^{4}$ As in practice, the government of the Luwu Union period has a monarchic pattern, with an administrative system that has a primordial

\footnotetext{
${ }^{3}$ Kusuma IC dan Andi Ima, Legacy Tana Lumu (Sulawesi Selatan: Dinas Kebudayaan dan Pariwisata Provinsi Sulawesi Selatan, 2015), 24.

4 Edward L Polinggomang, Kedatuan Luwu Dalam Perspektif Sejarab Sulawesi Selatan (Luwu Timur: Pemda Luwu Timur, 1995), 173-74.
}

pattern. Even so, the model of power that is built leads to public services, paying attention to the prosperity and peace of the people.

Edward L Polinggomang explained that in this relationship a tradition of supervision over the wealth of the ruler was built by recording his wealth before and after becoming Datu, a challenge that was built to limit and hinder the use of authority in the administration of the government in order to enrich themselves. In fact, in the administration of the government, a customary council organization was created which served to give advice and consideration and even form a joint policy with Datu, as a strategy to avoid the authority of political control holders. In this case, the Luwu Unity government system was monastic, but it was democratic. $^{5}$

Some of the concepts above, although with a very concise description, at least have become an important and integrated part of the past life of the Luwu Union; It cannot be denied that the messages mentioned above are not only normative, but the greatness, existence, and golden age of this kingdom have become evidence of how these concepts become evident in their application.

2. Village Fund Allocation (ADD)

Republic of Indonesia Government Regulation Number 72 of 2005 concerning Villages, village fund allocation is part of the central and regional financial balance funds received by the district / city for the village of at least $10 \%$, which is proportionally distributed to villages. ${ }^{6}$

Village Fund Allocation (ADD) According to Law Number 6 of 2014 concerning Villages is part of the balance fund received by regencies / cities at least 10\% (ten percent) in the regional income and expenditure budget after deducting special allocation funds. ${ }^{7}$

According to the Meranti Islands Regional Regulation Number 16 of 2011 concerning Village Finance that the village income and expenditure budget, hereinafter abbreviated as APBDesa, is an annual village financial plan that is discussed and agreed upon jointly by the village government and the Village Consultative Body (BPD) stipulated by the

\footnotetext{
5 Polinggomang, 181.

${ }^{6}$ Republik Indonesia, "Peraturan Pemerintah Republik Indonesia Nomor 72 Pasal 68 ayat (1)" (2005).

7 Republik Indonesia, "Undang-Undang RI Nomor 6" (2014).
} 
Village Regulation. ${ }^{8}$ Thus ADD is sourced from regional tax revenue sharing and part of the central and regional financial balance funds received by the district / city for the village.

\section{Methodology}

This research provides a systematic, careful description with a qualitative descriptive method that examines the planting of local values in the management practices of village budgetary budget allocations in Poringan Village, Suli Barat District, Luwu Regency. Data obtained through interviews and documentation are related to the theme of the research so that instruments are needed in the form of interview guidelines and supporting tools in obtaining documentation in the field.

\section{Result}

Every village has its own customs and local cultural values. This is based on the fact that the territory of Indonesia consists of various tribes, races, languages, ethins and cultures, making Indonesia a multicultural nation. In this multiethnic society's life, pluralism does not only imply differences, but it also contains reciprocal interactions between the Village Head and his community and or fellow community members. In such a society, the problem that usually arises is the difficulty of reaching an agreement in laying the foundation for a good and appropriate system of government, coupled with the decreasing moral ethics, this is related to the swift flow of change and the strong impact of globalization which can have a negative effect on living community and within the government itself. It appears that the weak attitude and critical power of the community results in a lack of ability to select negative values and global culture so that positive local wisdoms erosion occurs..

In this case, the role of the Village Head as a leader and all his devices is needed as an example and can protect his community not to be negatively affected by the current globalization by respecting and upholding local customs and values in his area. Based on the researchers' investigation, it was found that there were three local wisdoms that were still applied by policy makers in the Village of Poringan, Suli District, Luwu Regency in managing the Village budget. The moral values consist of:

\footnotetext{
8 Republik Indonesia, "Peraturan Daerah Kabupaten Kepulauan Meranti Nomor 16 , Pasal 1 Butir (12)" (2011).
}

\section{Adele (Fair)}

Literally, the word fair comes from fair Arabic which means in the middle. Justice means placing something in the middle, not one-sided or in other words fair means putting something in its place.

The aim of the Indonesian state is the fulfillment of justice for all the people of Indonesia, this is stated in the Opening of the 1945 Constitution and the fifth principle of the Pancasila. The message contained in the Preamble of the 1945 Constitution should be a guideline and encouragement for government administrators that the main task of the government is to create justice. Fair treatment to society indiscriminately. Humans are essentially the same as their dignity, including humans as countries. Therefore, state officials should guarantee fair treatment of their citizens.

From the understanding of the concept of Adele (fair) understood by researchers based on the philosophy of the Kingdom of Luwu, Adele (fair) can be interpreted as an act or behavior that is not biased, placing something in its place or not arbitrary. This is based on the results of interviews with the Head of Poringan Village who said that the fair was proportional. All do not have to be as many, but conditioned according to needs. ${ }^{9}$ Based on the results of the interview above, according to the Village Head of Poringan, fairness and proportional attitudes do not have to be shared equally, but put things according to community needs.

The same thing was also conveyed by Community Leaders and Indigenous leaders of the Village of Poringan that Adele was the same as putting something in its place. This attitude is very important for regional leaders, especially the Village Head, to remember that Poringan is an area that still maintains ancestral heritage. ${ }^{10}$

Based on the interview above, the Customary Leader believes that the local wisdom of Adele is a very important thing to understand, especially in Poringan Village. Because besides teaching good values, it is also a form of ancestral inheritance from the Kingdom of Luwu so that it has become an

\footnotetext{
${ }^{9}$ Kasman, Kepala Desa Poringan Kecamatan Suli Barat Kabupaten Luwu., t.t.

10 Haddini, Tokoh masyrakat Desa Poringan Kecamatan Suli Barat Kabupaten Luwu, 2018.
} 
obligation to be preserved and preserved by the next generation.

Universally the concept of justice can be widely known by every community, including government leaders. Where leaders know that justice is an act that does not discriminate and provide services equally to every community. But according to the aims and objectives of this study which tried to elevate local wisdom as a philosophy or special spirit in managing government there needs to be an understanding of the existence of this value in the culture of a nation or region especially for leaders.

The concept of justice which was actualized in the concept of leadership of the kings of Luwu has long relied on the philosophy put forward by I Sehe Makekunrai, namely Sinennimi adele mapparenta datu-e, while patappulo wenni sempajangnge. meaning: "The government that does justice overnight is the same as forty nights establishing a prayer." 11 From the search results through interviews and documentation, it was found that the adele concept in managing ADD was very real, among others by conducting budget discussions in a transparent manner and the community being the supervisor in the use of ADD.

\section{Lempu (Honest)}

In terms of language, honest is acknowledging, saying or giving information that is in accordance with what really happened / reality. Honest attitude is an attitude that attempts to adjust or match information with phenomena or reality. Honesty in the Indonesian language dictionary is a straightforward, sincere and sincere action.

As for honesty, according to Maccae Ri Luwu's thinking as a benchmark rather than the value of Lempu (honest), that is:

a. The person who is guilty of him is forgiven

b. He is trusted and does not betray that trust

c. Not greedy or not wanting what is not his right

d. He did not demand a good, if only he enjoyed it, only for his personal interests. ${ }^{12}$

Honest attitude is what comes out of the conscience of every human being and is not what comes out of the results of thoughts that involve the brain and lust. In another sense honesty is the value of goodness as a positive trait that is accepted by everyone, anytime and anywhere.

The results of interviews with the Village Secretary obtained by the author are related to understanding the value of lempu (honest) as follows: what is meant honestly is open, not covering up what actually happened, but will tell the truth according to the facts. The application in running the wheels of government the village apparatus must always be open, accept all the people both in the form of dissemination of information, assistance and transparency in the management of existing village funds budget allocations. ${ }^{13}$

The value of lempu that is understood by the informant is that it does not issue false words, carry out the mandate that has been given, as it is, straighten the things that are problematic and put things in place and be open in any case. In the theory of democracy, open government is an essential or important thing, especially the free access of every society to various sources of information, so that there is no mutual suspicion between individuals, society and the government. Openness in the implementation of each policy must be clear, not carried out in secret, confidential but planning, implementation, accountability can be known to the public and the public has the right to factual information about various matters relating to the making and implementation of policies.

\section{Getteng (Firm)}

Firm means that it remains and does not change hearts, and holds fast to what it thinks. A person who is called a firm stance if he has an opinion that is not easily changed and is called a person who does not have a position if he easily changes his opinion even easily influenced by the opinions of others.

Getteng (firm) is a behavior that adheres to the principles that have been made and is based on truth values (tongeng). In addition, according to Maccae Ri Lunu's thinking, there are several forms of behavior that can indicate that someone has a strong attitude, namely:

a. Do not deny promises and do not step over (betray) the agreement

b. Do not break down finished goods

c. Do not change decisions

\footnotetext{
${ }^{11}$ Fahri Rezki Rahman, “Aktualisasi Nilai Budaya Lokal dalam Kepemimpinan Pemerintahan di Kota Palopo" (Universitas Hasanudin, 2013), 34.

12 Rahman, 34.
} ${ }^{13}$ Jail, Sekretaris Desa Poringan Kecamatan Suli Barat
Kabupaten Luwu, t.t. 
d. When adjudicating, later it will break up then stop. ${ }^{14}$

Firm in stance is a person who is expected to be in the midst of society, only very few people are like that. This people's dignity will be very positive for the good of the community.

The following is the result of an interview with the Village Head about tense (steadfast) understanding as local wisdom in viewing the concept of constancy. Firm as well as firmness, firm in stance. Whatever responsibility is given is based on the rules that have been applied. Consistent with established rules. ${ }^{15}$

The same thing was also conveyed by Indigenous Village Leaders in Poringan: Firm in it contained a firm attitude, in accordance with the rules. As for what is called a firm stand, he will not leave a promise. The point is that when we have made a commitment or a promise, it must be kept and must be maintained as a form of consistency in carrying out tasks, especially the government. ${ }^{16}$

From the results of interviews with informants who understood Gteng's local cultural values it can be concluded that the intended getteng is not leaving promises or commitments that have been made, consistent in carrying out the mandate and responsibility, firmly acting accordingly, and not changing what has been decided.

These three local values are within 1 scope called integrity. A leader must have these three things if you want to lead. The community will feel peaceful and peaceful if the leader applies this value because there is no suspicion, the leader obeys the rules and does not discriminate between the people. Parable if the leader who does not have integrity, is like a deep and big river but it is not runny, then there will be no benefit from the river. If the river has clear, calm and clean water, then all the people will feel calm, cool and bring many benefits. ${ }^{17}$

The awareness of the importance of local values is one of the things that indicates that government leaders in determining their policies still pay attention to existing local

14 Rahman, "Aktualisasi Nilai Budaya Lokal dalam Kepemimpinan Pemerintahan di Kota Palopo," 34-35.

15 Kepala Desa Poringan Kecamatan Suli Barat Kabupaten Luwu.

16 Tokoh masyrakat Desa Poringan Kecamatan Suli Barat Kabupaten Luwu.

17 Tokoh masyrakat Desa Poringan Kecamatan Suli Barat Kabupaten Luwu. values. This is in line with the results of interviewing the author with the informants who understood in this study. Where the informant stated that the local cultural values of adele, lempu and getteng are a very important concept of value to be applied especially in order to support existing governance activities, especially in Poringan Village.

Because in addition to being a form of noble inheritance from the ancestors of the Kingdom of Luwu, the local values are very relevant to the teachings of religion that teach about the values of virtue and noble character. So that it can be used as a basis in acting and behaving primarily in organizing a system of government to realize good and right governance and still rely on local wisdom.

Related to this research, the intended application is the action and implementation of the concept of local values of adele, lempu, and getteng by the Village Head and his staff in carrying out their main tasks and functions, especially in managing village budget funds stipulated in legislation, both in the form of government regulations as well as regional regulations as outlined in the form of main tasks and functions.

What is meant by basic duty is the most basic task and must be carried out from a position or organization. The main task provides an overview of the scope or complexity of the position or organization. While the function is the realization of governance tasks in certain fields that are implemented in order to achieve national development goals. Functions can also be interpreted as a group of activities belonging to the same type based on the nature or implementation.

A leader is someone who has the ability to regulate the form of government effectively and efficiently. In order for order to occur, arrangements are needed regarding the division of tasks, ways of working and the relationship between one job and another. This regulatory activity is called administration, which needs to be controlled or led by a leader.

\section{Conclusion}

Based on the previous discussion, it can be concluded that the application of local values in the management of village fund allocation in Poringan Village, Suli Barat District, Luwu Regency uses the concept of adele (fair). This concept can be seen in the allocation and use of ADD where the community is directly involved, 
lempu (honest), that is by accepting all of its people both in the form of disseminating information, assistance and transparency in the management of existing village budget funds, and gaining (steadfast), namely by means of firmness, firm in their stance. Whatever responsibility is given is based on the rules that have been applied. Consistent with established rules.

\section{References}

Ghozal. Abdullah, Dindin. Kader Desa : Penggerak Prakarsa Masyarakat Desa. Jakarta: Kementrian Desa, Pembangunan Daerah Tertinggal, dan Transmigrasi Republik Indonesia, 2015.

Haddini. Tokoh masyrakat Desa Poringan Kecamatan Suli Barat Kabupaten Luwu, 2018.

I Made Pasek, Diantha. Hukum Pidana Internasional ; dalam Dinamika Pengadilan InternasionalI. Jakarta: Kencana Prenada Media, 2-14.

Jail. Sekretaris Desa Poringan Kecamatan Suli Barat Kabupaten Luwu, t.t.

Kasman. Kepala Desa Poringan Kecamatan Suli Barat Kabupaten Luwu., t.t.

Kusuma IC, dan Andi Ima. Legacy Tana Luwn. Sulawesi Selatan: Dinas Kebudayaan dan Pariwisata Provinsi Sulawesi Selatan, 2015.

Polinggomang, Edward L. Kedatuan Luwn Dalam Perspektif Sejarah Sulawesi Selatan. Luwu Timur: Pemda Luwu Timur, 1995.

Rahman, Fahri Rezki. "Aktualisasi Nilai Budaya Lokal dalam Kepemimpinan Pemerintahan di Kota Palopo." Universitas Hasanudin, 2013.

Republik Indonesia. Peraturan Daerah Kabupaten Kepulauan Meranti Nomor 16 , Pasal 1 Butir (12) (2011).

Peraturan Pemerintah Republik Indonesia Nomor 72 Pasal 68 ayat (1) (2005).

. Undang-Undang RI Nomor 6 (2014). 